\title{
Удк 331.108.2
}

I. В. Хохлова, аспірантка кафедри "Облік і аудит" Державний економіко-технологічний університет транспорту

\section{АУТСТАФІНГ (ВИВЕДЕННЯ ЗА ШТАТ) ПЕРСОНАЛУ: ПРОБЛЕМАТИКА ТА ПЕРСПЕКТИВИ В СУЧАСНИХ ЕКОНОМІЧНІХ УМОВАХ УКРАЇНИ}

У статті розглянуто актуальні питання щодо вдосконалення процесів, пов'язаних з управлінням персоналом, мінімізації адміністративних витрат і ризиків підприємств, відповідно до цього розкрите поняття та сутність терміну "аутстафінг", актуальність його використання, проблематика та перспективи розвитку в сучасних економічних умовах України.

К л ю ч о в і с л о в а : аутстафінг, адміністрування, мінімізація адміністративних витрат, управління персоналом.

Постановка проблеми. Сучасний бізнес є динамічним і вимагає достатньої гнучкості, саме тому вітчизняні підприємства змушені йти в ногу 3 часом, модернізуючи не тільки своє виробництво, маркетингові стратегії, але й витрачаючи певні матеріальні та часові ресурси на удосконалення своєї кадрової політики. На сьогоднішній день управління персоналом давно вже вийшло за рамки просто виплати заробітної плати і ведення кадрового документообігу. Це зважена й цілеспрямована політика найму, мотивації та розвитку персоналу за умови досягнення максимальної ефективності його використання. Найбільш актуальним питанням сьогодення $\epsilon$ розвиток та вдосконалення процесу управління персоналом, оскільки це невід'ємна частина успішного та динамічного розвитку підприємства. Одним з найбільш дієвих методів досягнення поставлених цілей у питанні підвищення ефективності бізнесу за умови мінімізації адміністративних витрат і ризиків сьогодні служить аутстафінг. Саме за останні роки кількість послуг у галузі підбору, розвитку й адміністрування персоналу значно зросла. Рівень розвитку бізнесу і його темпи вимагають від провайдерів (надавачів) цих послуг розробки та адаптації новітніх процедур, актуальних у даний час у нашій країні.

Аналіз основних досліджень і публікацій. Вагомий внесок у дослідження та розкриття актуальних проблем аутстафінгу внесли та займаються до сьогодні вітчизняні вчені В. Бєлікова, Є. Благодарна, А. Соколова, Є. Дерев'янко, Т. Лагода, О. Коняєва, Л. Тетянич та інші. 


\section{ЕКОНОМІКА}

Метою статті є розкриття поняття та сутності аутстафінгу, поглиблене вивчення різних його аспектів, актуальність використання, проблематика та перспективи розвитку в сучасних економічних умовах України.

Викладення основного матеріалу. Передусім визначимо походження терміна "аутстафінг" та розкриємо його призначення. Аутстафінг (англ. outstaffing у перекладі означає "out" - вивід, "staffing" - штат, тобто виведення за штат). Призначення цієї послуги поширюється в галузі кадрового адміністрування з виведення персоналу за штат компанії-замовника та оформлення його в штат компанії-провайдера. Цей інструмент в управлінні персоналом дозволяє компаніям регулювати кількість працівників, не змінюючи при цьому офіційну чисельність персоналу. При цьому провайдер бере на себе повну юридичну відповідальність за персонал, включаючи ведення кадрового діловодства й бухгалтерії, виплату заробітної плати з відрахуванням зарплатних зборів до соціальних фондів, виконання норм трудового законодавства України (прийом на роботу, звільнення, рішення трудових спорів тощо), оформлення щорічних відпусток, лікарняних листів, відряджень, здійснення соціального і медичного страхування. У свою чергу працівники продовжують працювати на своєму робочому місці та виконувати свої посадові обов'язки, але обов'язки роботодавця стосовно до них виконує вже провайдер. Тобто працівники укладають трудові договори не із замовником, а з провайдером. Передумови для використання цієї послуги є типовими для сучасних компаній:

1) зростаюча складність і додаткові вимоги законодавства в галузі кадрового обліку;

2) менеджер витрачає багато часу на вирішення адміністративних питань з трудових відносин;

3) велика кількість постійних співробітників у штаті компанії робить іiі менш гнучкою і більш залежною від персоналу;

4) прагнення до більшої гнучкості та незалежності при формуванні "штатного розкладу";

5) прагнення до скорочення адміністративних витрат на управління персоналом.

Перевагами для підприємств, що використовують послуги аутстафінгу, є:

1. Скорочення штатної чисельності персоналу при збереженні фактичною;

2. Оформлення тимчасового персоналу;

3. Оформлення співробітників на час випробувального терміну і продовження випробувального терміну;

4. Зниження адміністративних і фінансових витрат;

5. Забезпечення легальності та юридичної підтримки при роботі з персоналом;

6. Можливість сконцентруватися на основному бізнесі;

7. Підвищення конкурентоспроможності компанії. 
Історія зародження та розвиток аутстафінгу. Початок розвитку аутстафінгу у світі відносять на кінець $60-\mathrm{x}$ - початок 70-х рр. минулого століття. Саме тоді в США виникла і набула поширення концепція позикової праці. Пов'язано це було з особливостями федерального законодавства, відповідно до якого підприємства за допомогою технології лізингу персоналу спроможні були використовувати більш вигідні схеми пенсійного страхування співробітників. У 1982 р. через визнання лізингу методом ухилення від податків відповідне положення в законодавстві було скасовано. За даними Американської адміністрації малого бізнесу, в період 1982-2000 рр. кількість трудових актів, що регулюють трудові відносини в США, збільшилася на $60 \%$, що призвело до необхідності підприємствам, особливо малим і середнім, витрачати на оформлення кадрової документації не менше $25 \%$ свого робочого часу. Проте технологія продовжувала розвиватися і 3 часом з'явилася така форма, як аутстафінг персоналу. Зручність і явні вигоди від використання цієї послуги спонукали вже до 2005 р. більш як 80\% малих і середніх підприємств країн Заходу виводити своїх співробітників за штат. На сьогоднішній день тільки в США послугу аутстафінгу пропонують понад 2000 компаній, і цей ринок показує середній приріст на рівні $35 \%$ щорічно. Аналогічна ситуація в Західній Європі позиціонує аутстафінг як послугу, яка дає можливість підприємствам концентруватися на своєму основному бізнесі та не відволікатися на побічні завдання. На даний час у США аутстафінг - це законодавчо оформлена послуга з чітко проробленим механізмом реалізації.

Попит на послуги $з$ аутстафінгу персоналу в Росії вперше виник після дефолту 1998 р., коли іноземні компанії, що залишилися на російському ринку, були змушені частково скорочувати співробітників і виводити їх за штат. Період середини 2002 р. - початку 2003 р. характеризувався найбільшим зростанням попиту на цю послугу, що істотно вплинуло на збільшення загального обсягу ринку кадрових послуг у Росії (більше 100 млн дол. США), і до кінця 2004 р. вітчизняні клієнти вже становили 40\% від загальної кількості фірм, які звернулися до провайдерів. На даний момент частка аутстафінгу на ринку кадрових послуг дорівнює $20 \%$. Той факт, що на російському ринку аутстафінг за останні три роки зріс у чотири рази, свідчить про посилення юридичної складової бізнесу. Це дає можливість російським кадровим агентствам заявляти про те, що ця послуга - одна 3 найперспективніших.

В Україні послуга аутстафінгу з'явилася в 1999 р., отримавши значне поширення після 2004 р. Першими й основними іiі споживачами стали великі транснаціональні корпорації, які використовують цю форму адміністрування персоналу і вважають іï найбільш комфортною та економічно вигідною. На сьогоднішній день ця послуга $є$ недооціненою українськими підприємствами в силу недостатньої інформації та розуміння переваг та особливостей ії̈ використання на практиці.

\section{2}




\section{ЕКОНОМІКА}

При вивченні законодавчих аспектів та організаційно-правового підгрунтя, було виявлено, що визначення аутстафінгу до 2010 р. не знаходило чіткого відображення в українському законодавстві. Якщо вважати, що всі учасники господарських відносин є вільними в укладенні договорів як передбачених, так і не передбачених Цивільним кодексом України, то при укладанні угод з послуги аутстафінгу зазвичай складають договір на надання послуг. Суть його полягає в тому, що провайдер зобов'язується за завданням замовника надати певні послуги, а останній зобов'язаний їх оплатити. Після укладення договору про надання послуг співробітники, що виводяться за штат компанії-замовника оформлюються у штат до компанії-провайдера, з працівниками укладаються трудові договори. Таким чином, вивід персоналу за штат компанії-замовника та прийняття в штат компанії-провайдера потрапляє під сферу діяльності трудового законодавства. Надання послуг/виконання робіт силами виведеного персоналу через провайдера регламентується нормами цивільного і трудового права. Ситуація до певної міри змінилася після прийняття Податкового кодексу України від 02.12.2010 р. № 2755-VI (далі - ПКУ), в якому з'явилося визначення поняття послуги з надання персоналу. Згідно з ПКУ послуга з надання персоналу - це "господарська або цивільно-правова угода, згідно з якою особа, що надає послугу (резидент або нерезидент), відправляє в розпорядження іншої особи (резидента або нерезидента) одну або кілька фізичних осіб для виконання визначених цією угодою функцій". Таким чином, сформувалася законодавча база для використання аутстафінгу на практиці.

На теперішній час існують такі санкції, встановлені законодавством України: за ухилення від оформлення трудових відносин - 34000 грн за кожного неоформленого працівника; за порушення термінів виплати зарплати до 8500 грн (ст. 41 Кодексу України про адміністративні правопорушення далі КпАП), а також для керівника - позбавлення волі на строк до 5 років (ст. 175 Кримінального кодексу України - далі КК); за відмову працівника від дачі пояснень посадовим особам органів нагляду - до 18820 грн (ст. 188-6 КпАП); за нарахування та виплату зарплати в сумі нижче встановленого законом розміру мінімальної зарплати - від 8000 до 25000 грн або позбавлення волі до 3 років (ст. 175 КК України).

Розглянемо можливі наслідки для компанії при недотриманні законодавчих вимог: зростання витрат на податки та збори від 2 до 8 разів, залежно від рівня зарплати; значно посилиться тиск на бізнес з боку контролюючих органів; істотно збільшаться витрати підприємства на адміністрування зарплат; пропорційно із зростанням витрат на податки і збори знизиться рівень рентабельності і прибутковості бізнесу; у разі застосування зазначених штрафних санкцій виникає висока ймовірність банкрутства підприємства.

Щоб дослідити ринок послуг аутстафінгу в Україні, були розглянуті найбільш поширені пакети послуг. 
Зазвичай українські компанії-провайдери пропонують стандартний пакет послуг у рамках договору:

- зарахування до штату та оформлення трудових відносин з працівниками будь-якого регіону України;

- розрахунок, своєчасне нарахування та виплата заробітної плати співробітникам;

- розрахунок і виплата допомоги з тимчасової непрацездатності та компенсацій за відпустку, оформлення витрат на відрядження;

- нарахування та перерахування податків у встановлені законодавством фонди;

- оформлення необхідних бухгалтерських звітів і довідок;

- проведення всіляких кадрових процедур у відповідності з трудовим законодавством України;

- здача квартальних та річних звітів щодо єдиного соціального податку, страхових внесків на обов'язкове пенсійне страхування;

- підбір співробітників.

Менш поширеною, але актуальною послугою від компаній-провайдерів є вивід іноземного персоналу за штат компанії. До циєё послуги входить:

- оформлення всіх необхідних дозвільних документів, які дають право іноземному працівникові перебувати і здійснювати трудову діяльність на території України;

- ведення всіх кадрових процедур у відповідності з трудовим законодавством України;

- розрахунок і виплата допомог з тимчасової непрацездатності та компенсацій за відпустку, оформлення витрат на відрядження;

- управління компенсаційним пакетом співробітників;

- припинення трудових відносин з працівником на вимогу замовника;

- переведення за бажанням замовника співробітника на постійну роботу до свого штату з оформленням усіх необхідних дозвільних документів, які дають право замовнику залучати до роботи, а іноземному працівникові - працювати в останнього.

- щомісячний розрахунок та виплата заробітної плати;

- відкриття індивідуального банківського рахунку для переказу заробітної плати;

- розрахунок і відрахування встановлених прибуткових і соціальних податків;

- оформлення необхідних бухгалтерських звітів і довідок.

Компанї-провайдери визначають такі переваги ции послуг, а саме:

- зниження витрат, пов'язаних з адмініструванням персоналу;

- податкові переваги як для замовника, так і для співробітників замовника;

- зниження вартості документообігу; 


\section{ЕКОНОМІКА}

- забезпечення повної легальності роботи з персоналом;

- оформлення всіх дозвільних документів іноземним працівникам відповід-

но до чинного міграційного законодавства України;

- гарантія дотримання всіх норм трудового, податкового та міграційного законодавства.

- відсутність адміністративної та кримінальної відповідальності за незаконне використання іноземної робочої сили;

- надійна юридична підтримка;

- додаткові мотиваційні програми;

- збереження штатної чисельності без зміни фактичної, відповідність штатним розкладом;

- більш гнучке кадрове планування.

Для наочного висвітлення проблематики залучимо дані соціологічних досліджень. Компанія "Ернст енд Янг" та Група компаній "Рост", провели у 2013 р. "Дослідження з використання послуг кадрового аутстафінгу на ринку України"1. Фахівці групи Human Capital, одного з підрозділів "Ернст енд Янг", надають інформацію про практику використання послуг кадрового аутстафінгу компаніями на ринку України: про причини звернення до таких послуг, їх актуальності, плюси і мінуси. У дослідженні взяли участь близько п'ятдесяти компаній з галузей: автомобільна, хіміко-фармацевтична, аграрна, агрохімічна, банківський сектор, готельний бізнес і туризм, торгівля та споживчі товари, страхування і телекомунікації/інформаційні технології, а також транспорт/логістика. Кожен третій учасник опитування зазначив, що знайомий 3 поняттям аутстафінгу поверхнево, близько $60 \%$ учасників поки ще не використали аутстафінг. Проте можливість застосування аутстафінгу в майбутньому зазначив кожен другий респондент. Для прийняття рішення про виведення співробітників за штат компанії учасники вважають корисною інформацію про економічну доцільність, а також практичний досвід компаній, що використовують аутстафінг персоналу. Ті, хто співпрацював 3 провайдерами послуг аутстафінгу, вказали такі сильні сторони цих провайдерів, як гнучкість, адекватна вартість послуг, виконання зобов'язань перед партнерами, належна якість послуг. У дослідженні взяли участь представники як великих компаній із штатом більше 1000 співробітників (45\%), так і дрібніших, що мають штат до 200 осіб (29\%). У процесі дослідження було виявлено, що найчастіше потребу в аутстафінгу відчувають торгові компанії (на це вказали $14,8 \%)$, компанії, що працюють у сфері туризму та готельного бізнесу $(12,9 \%)$. Висока потреба в аутстафінгу на виробництві $(9,1 \%)$, в будівництві $(8,3 \%)$, в харчовій промисловості (4,9\%) (рис. 1$)$.

\footnotetext{
${ }^{1}$ Результати дослідження та найактуальніші аспекти співпраці при наданні послуг аутстафінгу персоналу, було обговорено під час проведення експертної конференції, яка відбулася 2 квітня 2013 р.
} 


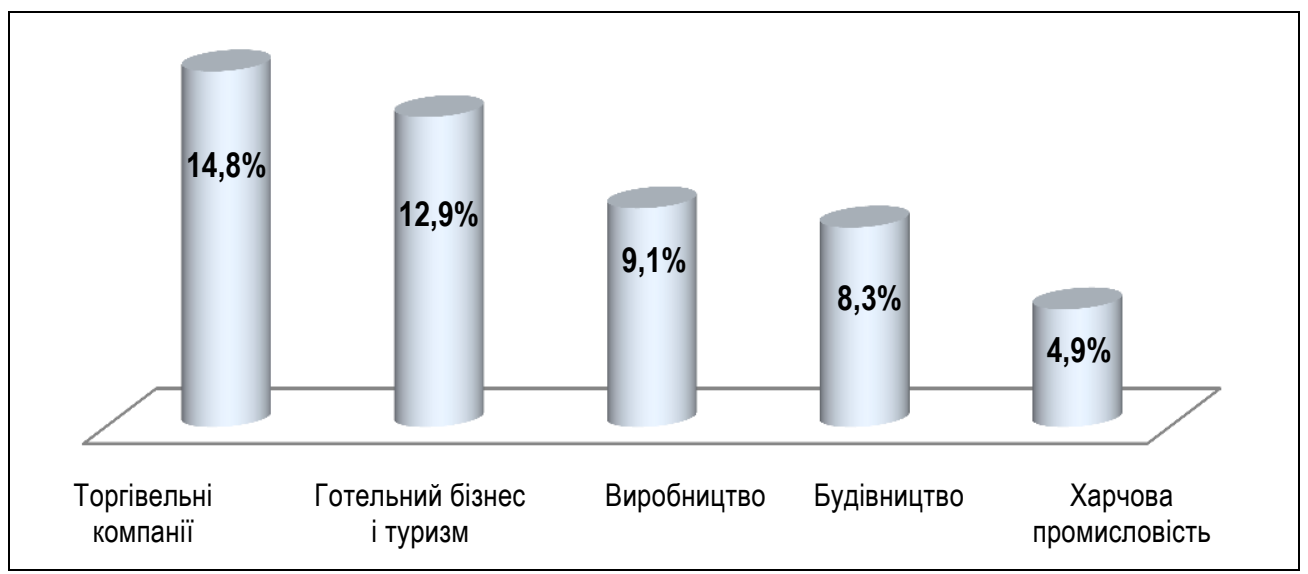

Рис. 1. Потреба у використанні послуги аутстафінгу, \%

Незважаючи на те, що потребу у використанні аутстафінгу відчувають $60 \%$ підприємств українського ринку, можливості для цього є лише у $2 / 3$ 3 цих підприємств. Однак, на думку $5 \%$ респондентів, що взяли участь в опитуванні, їх компанії не мають можливості використовувати таку послугу, хоча мають велику потребу в ній.

Опитані 24,6\% компаній, які користуються послугою аутстафінгу, зазначили, що головна мета використання цієї послуги - зниження витрат. Ще $20,8 \%$ респондентів вирішили таким чином оптимізувати управління людськими ресурсами, а 15,3\% за допомогою аутстафінгу вирішують проблему регламентації штату. I, нарешті, 9,2\% респондентів, що взяли участь в опитуванні, використовують аутстафінг для того, щоб сконцентруватися на основному бізнесі. На інші цілі вказали $30,1 \%$ респондентів. Серед них: вирішення разових завдань, неможливість своїми силами в короткі терміни підібрати персонал на виробництво, відсутність досвіду і власного персоналу або тимчасова заміна співробітників на період відпусток (рис. 2).

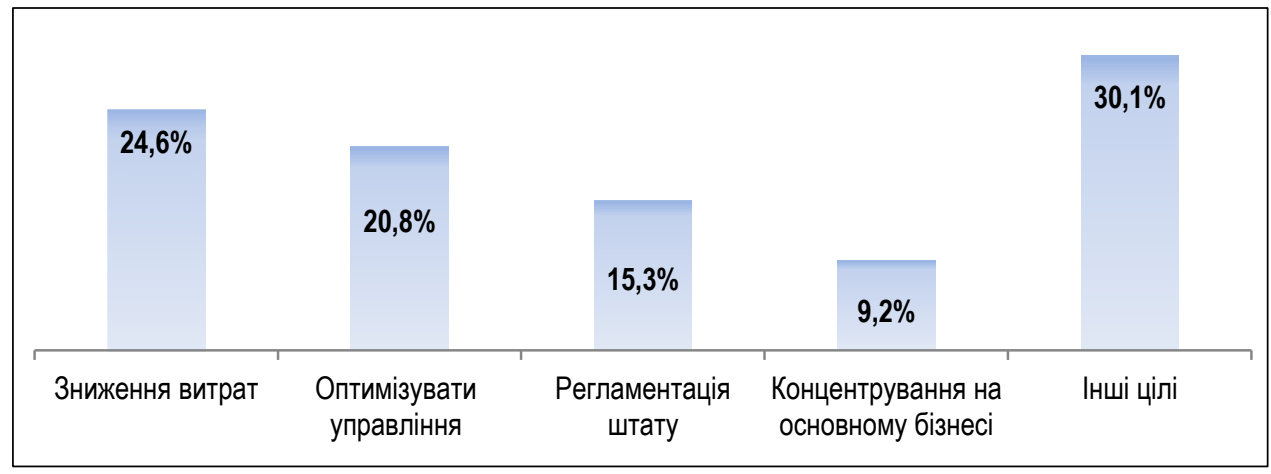

Рис. 2. Цільові частини використання аутстафінгу, \% 


\section{ЕКОНОМІКА}

Компанії-замовники у практиці використання цієї послуги зіштовхнулися 3 позитивними і негативними факторами. Серед переваг аутстафінгу фактичні роботодавці називають: зниження витрат з кадрового адміністрування (цими проблемами займається провайдер, так само як і розрахунками, перерахуванням податків, документацією), відсутність проблем з набором персоналу і пошуком відповідних співробітників, зниження витрат на залучення й утримання персоналу, управління витратами і можливість залучення персоналу для сезонних робіт без оформлення в штат.

Однак, послуга 3 аутстафінгу досі залишається недосконалою і не виваженою до кінця. Слід відзначити брак законодавчих документів, які б у повному обсязі регулювали взаємовідносини компанії-замовника, компанії-провайдера і працівника, якого наймають на роботу за допомогою аутстафінгу. Тому працівник може опинитися в незахищеному становищі, оскільки його статус до кінця не визначений і не підпадає ні під одне положення з уже існуючих в законодавстві. Фактично працівник, оформлений за трудовою книжкою, але вона знаходиться не в тій компанії, де він реально працює, а в компанії-провайдері. Таким чином, запис у його трудовій книжці не відповідає тій реальності, яка існує. У зв'язку із цим працівники неохоче погоджуються виходити за штат компанії. Але $є$ вихід 3 цієї непростої ситуації. Компаніяпровайдер і компанія, в якій реально працює співробітник, надають рекомендаційні листи з поясненнями виникнення нестиковок між записом у трудовій книжці працівника і реально існуючим робочим місцем.

Але крім запису в трудовій книжці існують інші проблеми для працівників - це відсутність гарантій. Пропозиція оформитись на роботу через іншу компанію, яка фактично не працює, дуже насторожує працівників. I це цілком природно. Ще одна причина, з якої багато працівників відмовляються ставати аутстаферами, - це відсутність у компанії-провайдера, в якій вони формально будуть оформлені в штат, відомого імені, бренду, суспільного іміджу. Отже, існує ряд психологічних факторів, які впливають на думку працівників про аутстафінг у цілому і змушують багатьох відмовлятися від роботи в досить престижних компаніях. Психологічна підтримка з боку материнської компанії відіграє ключову роль у формуванні прихильності працівника до такого способу оформлення трудових відносин з підприємством. Тож оскільки послуга $з$ аутстафінгу на сьогоднішній день не $є$ розвиненою для нашої країни, то й довіра працівників до такого способу працевлаштування досить мала. Але зазвичай у компанії-провайдері на багато краще дбають про працівників, найнятих за допомогою аутстафінгу, оскільки саме це $\epsilon$ їх прямим призначенням. Материнська компанія може, таким чином, не хвилюватися про комфортність умов їх праці та повну юридичну підтримку з боку провайдера. Власне, саме за це йому платять гроші.

На даний момент в нашій країні аутстафінг ще тільки на стадії розвитку, тому компаніям-замовникам слід здійснювати вибір провайдера дуже 
уважно та ретельно перевіряти на рівень компетенції. В іншому разі можна натрапити на непрофесіоналів та отримати безліч проблем. А головна мета послуги аутстафінг - якраз уникнути правопорушень та проблемних наслідків. Для запобігання негативним наслідкам необхідно враховувати пріоритети при виборі компанії-провайдера. Рейтинг пріоритетних складових, набутих із практики при виборі компанії-провайдера, запропонований опитаними респондентами:

I. Репутачія, набута компанією-провайдером за роки своєї діяльності. Адекватна вартість пропонованих послуг, не завищена у порівнянні з ринковою ціною.

II. Сервісна політика та надійність компанії-провайдера гарантує стабільність усіх бізнес-процесів компанії-замовника та захист від негативних наслідків.

III. Індивідуальний niдxid, лояльне та гнучке ставлення до замовника, орієнтованість на клієнта.

IV. Гарантія конфіденційності, стратегічно важливо непоширення будьякої інформації стосовно документів, які надаються для роботи провайдеру, що є невід’ємною частиною доброякісного виконання послуг.

Висновки. За допомогою аутстафінгу багатьом компаніям вдалося вирішити цілу серію проблем: одні втамували "кадровий голод", інші змогли набрати низовий персонал на вакансії, які важко заповнюються, і молодший операційний персонал. Багато підприємств відзначили зниження витрат на чисельності та адмініструванні персоналу, гнучкість в управлінні людськими ресурсами, оптимізацію штатного розкладу, підвищення комплектності співробітників і закриття проблеми високої плинності кадрів.

При використанні послуги з аутстафінгу персоналу підприємство не несе жодних ризиків і штрафних санкцій за недотримання існуючих нормативів, установлених законодавством України. Навіть при штаті у 500 працівників чи більше підприємство може залишатися в статусі малого підприємства. Немає ризиків штрафу за невиплату, невчасну або неправильну виплату заробітної плати. Немає необхідності вести кадровий облік, витрачати кошти на додатковий персонал. За формально невеликої чисельності і відносно низьких витрат на персонал поліпшуються фінансові показники в розрахунку на одного співробітника (прибуток, обсяг продажів, інвестиційна привабливість і т.п.). Ця послуга може використовуватися як інструмент збільшення інвестиційної привабливості підприємства.

Деякі рекрутингові компанії вже сьогодні збільшують частку аутстафінгу в своєму бізнесі. У першу чергу, цьому сприяють стабілізація і зростання економіки в країні, а також збільшення частки західних компаній на ринку. Тенденції розвитку аутстафінгу в Україні багато в чому схожі на історію розвитку цієї послуги на Заході, де іiі поява на ринку стала можливою 


\section{ЕКОНОМІКА}

тільки тоді, коли ринок досяг певного рівня цивілізованості, коли законодавча складова бізнесу збільшується настільки, що сама перетворюється на бізнес. На даний момент цей рівень в Україні досягнутий. Ще залишилися негативні наслідки у вигляді "сірих" зарплат, але тенденція явно в бік відходу від подібної практики. Коли платити "білу" зарплату стане вигідно, тоді можна буде заявити про серйозну перемогу в цьому напрямі. У цей момент аутстафінг перетвориться на повсякденну реальність. Відповідно, збільшенню попиту на послуги з аутстафінгу сприятиме більш чітка розробка юридичної бази з надання цієї послуги.

1. Податковий кодекс України // Відомості Верховної Ради України (ВВР), від 02.12.2010 № 2755-VI [Електронний ресурс]. - Доступний 3 : <http:// zakon2.rada.gov.ua/laws/show/2755-17/page>.

2. Дослідження компанії "Ернст енд Янг" та Група компаній "Рост" [Електронний ресурс]. - Доступний $3:<\mathrm{http}: / /$ grouprost.com/ua/Новости/1180>.

3. Куликов Л.М. Основи економічних знань / Л.М. Куликов. - М. : Фінанси і статистика, 2005. - 48 с.

4. Мухін Ю.І. Наука управляти людьми: виклад для кожного / Ю.І. Мухін. М. : Фолиум, 2006. - $120 \mathrm{c.}$

5. Шермет А.Д. Методика фінансового аналізу підприємства / А.Д. Шермет, Р.С. Сайфулін. - М. : ИНФРА, 2006. - 88c.

6. Анікін Б.А., Рудая І.Л. Аутсорсинг і аутстафінг. Високі технології менеджменту. -2009.

7. Білозубенко В.С. Міжнародний менеджмент : навч. посіб. / В.С. Білозубенко, О.В. Озаріна, А.А. Семенов ; за ред. проф. О.Б. Чернеги. - К. : Центр навч. літ., 2006. -592 c.

8. Бєлікова В. Аутстафінг: проблеми застосування та шляхи їх подолання // Менеджмент і менеджер. - 2007. - № 6. - С. 4-9.

9. Благодарна Є. Піти, щоб залишитися / Є. Благодарна, А. Соколова // Office. -2005 . - № 5. $-26-32$ c.

\section{References}

1. Podatkovij Codeks Ukraini (VidomostiVerkhovnaRadaUkraini (VRU), vid 02.12.2010 № 2755-VI [Electronniy resurs]. Dostupno z: http://zakon2.rada.gov.ua/ laws/show/2755-17/page [in Ukrainian].

2. Doslidzhennya kompaniy "Ernst Young and Sea" ta Grupa kompaniy "Rost" [Electroniy resurs]. Dostupno z: http://grouprost.com/ua/Novosti/1180 [in Ukrainian].

3. Kulikov L.M. Osnovy ekonomichnykh znan. Moskva, Finansy i statystyka, 2005, 48 s. [in Ukrainian].

4. Muhin Yu.I. Nauka upravlyaty ludmy: vyklad dlia kozhnogo. Moskva, Folium, 2006, 120 s. [in Ukrainian]. 
5. Shermet A.D., Sayfulin R.S. Metodika finansovogo analizu pidpryiemstva. Moskva, INFRA, 2006, 88 s. [in Ukrainian].

6. Anikin B.A., Ruda I.L. Outsorcing i autstafing. Visoki tehnologiy menedzhmentu, 2009 [in Ukrainian].

7. Bilozubenko V.S., Ozarina O.V., Semenov A.A. Mizhnarodnyi menedzhment. Navchalnyi posibnyk; za red. O.B. Chernega. Kyiv, Centr navchalnoi literatury, 2006, 592 s. [in Ukrainian].

8. Bielikova B. Autstafing: problem zastosuvannia ta shliakhy yih podolannia. Menedzhment i menedzher, 2007, № 6, 4-9 s. [in Ukrainian].

9. Blagodarna Ye., Sokolova A. Pity, shchob zalyshytysia. Office, 2005, № 5, 26$32 \mathrm{~s}$. [in Ukrainian].

Отримано 14.11.13

И. В. Хохлова аспирантка кафедры "Учет и аудит"

Государственный экономико-технологический университет транспорта

АУТСТАФФИНГ (ВЫВОД ЗА ШТАТ) ПЕРСОНАЛА:

ПРОБЛЕМАТИКА И ПЕРСПЕКТИВЫ В СОВРЕМЕННЫХ

ЭКОНОМИЧЕСКИХ УСЛОВИЯХ УКРАИНЫ

В статье рассмотрены актуальные вопросы совершенствования процессов, связанных с управлением персонала, минимизации административных расходов и рисков предприятий, согласно этому раскрыто понятие и сущность термина "аутстаффинг", актуальность его использования, проблематика и перспективы развития в современных экономических условиях Украины.

Ключевые слова: аутстаффинг, администрирование, минимизация административных расходов, управление персоналом.

I. Khokhlova, PhD student

State Economy and Technology University of Transport

\section{OUTSTAFFING: PROBLEMS AND PROSPECTS IN THE CURRENT ECONOMIC CONDITIONS OF UKRAINE}

The article considers the current problems of improving the processes connected with human resource management and the minimization of enterprises' administrative costs and risks. Revealed is the concept and the essence of the term "outstaffing", the relevance of its use, problems and prospects of development in modern economic conditions of Ukraine.

Keywords: outstaffing, administration, minimization of administration cost, human resource management. 